\title{
A Preliminary Study of Brain-Based Learning (BBL) and Intrapersonal Intelligence in Junior High School Mathematics Learning
}

\author{
Edy Mastoni ${ }^{1,2, *}$, M. Syarif Sumantri ${ }^{1}$, Nurdin Ibrahim ${ }^{1}$ \\ ${ }^{1}$ Department of Educational Technology, Universitas Negeri Jakarta, Indonesia \\ ${ }^{2}$ STKIP Muhammadiyah Bangka Belitung, Indonesia
}

Received July 9, 2019; Revised September 9, 2019; Accepted September 16, 2019

Copyright $@ 2019$ by authors, all rights reserved. Authors agree that this article remains permanently open access under the terms of the Creative Commons Attribution License 4.0 International License

\begin{abstract}
The purpose of this study is to describe junior high school mathematics learning activities and describe the suitability of the Brain-Based Learning (BBL) learning strategy which focuses on intrapersonal intelligence in junior high school mathematics learning. The research is descriptive and qualitative. The data were collected through documentation studies, observations, and interviews with teachers and students. Teachers and students of junior high school SMP Assahil Lampung Timur Indonesia were involved in this research. The results showed that teachers only used expository learning strategies in learning activities and unsatisfactory learning outcomes. The teachers were never selecting learning strategies which focus on students' internal factors to be applied in learning. Based on these, taking into account the characteristics of learning strategies, students and junior high school mathematics material, it can be assumed that the Brain-Based Learning (BBL) learning strategy by focusing on students' intrapersonal intelligence is appropriate to be applied in junior high school mathematics learning and to enhance student's learning outcomes.
\end{abstract}

Keywords Brain Based Learning (BBL), Intrapersonal Intelligence, Junior High School Mathematics Learning, Learning Outcomes

\section{Introduction}

The implementation of learning strategies is believed to facilitate the achievement of the desired learning goals, namely improvement, and improvement of students' competence (Eggen \& Kauchak, 2012). In the learning process, there is an educative interaction between teacher and students. The teacher, as a learning designer, must be able to determine the right learning strategy to be applied. The choice of learning strategies is based on the characteristics of subjects and the needs of students (Silver, Strong, \& Perini, 2012). Many things need to be considered related to the needs of these students including new abilities, attitudes, motivation, independence, learning styles including the varying level of intelligence of students. Conformity to all aspects makes it easy to achieve the stated learning goals.

Benchmarks for the achievement of learning objectives can be seen from students' learning outcomes of the subjects being taught. Through learning outcomes, it can be known to what extent students have competencies by the set learning objectives. Students' learning outcomes for each subject taught in school are reported by subject teachers. Subject teachers determine students' learning outcomes based on specific assessment indicators. The assessment indicators for measuring the achievement of students' competencies in the subject matter learned were carried out through formative and summative tests.

Generally, mathematics is a difficult subject for many students. It can be seen from the many mathematics learning outcomes of students who are not satisfactory. This condition occurs in many schools both public and private schools. SMP Assahil Lampung Timur, one of the private junior high school, also experienced this. The results of the mathematics learning of SMP Assahil students can be said to be unsatisfactory. This condition can be seen from the achievements of the national exam results for the last three years. The following is a graph of the achievement of the SMP National Examination (UN) for the previous three years based on data obtained from the academic year. 


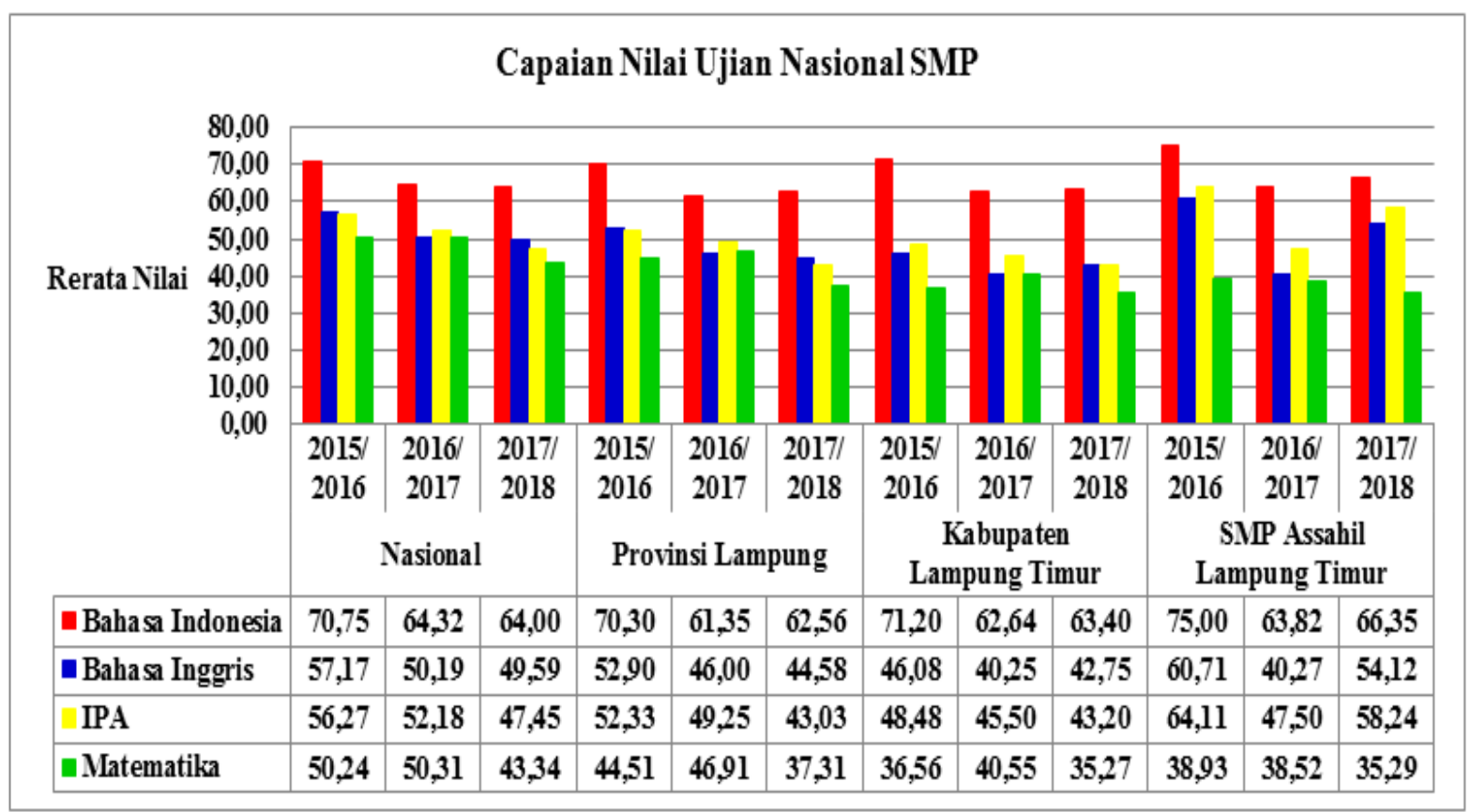

Source: processed based on data from The Ministry of Education and Culture of Indonesia

Figure 1. Achievement of SMP national exam scores, school year 2015/2016-20172018

The above graph shows that of all subjects tested in the SMP UN, among which the lowest UN scores were math subjects. This condition occurs almost every year in the past three years nationally, Lampung Province, East Lampung regency and school level as in SMP Assahil. The lowest average score of the National Examination in SMP Assahil during the last three years is also on mathematics subjects. In the previous three years, the number of achievement scores in the mathematics UN at SMP Assahil has always dropped every year. In contrast to several other subjects that can exceed the achievements of the district, provincial and even national levels, the achievement of the average score of mathematics UN at SMP Assahil has always been below provincial and national achievements over the past three years.

The low level of mathematics learning outcomes of the students of SMP Assahil indicates that they need improvement in the learning process. The primary growth is the teacher's ability to prepare the right Learning Implementation Plan (RPP). The lesson plan made by the teacher must be following the characteristics of the junior high school mathematics subject matter. The teacher must also understand the aspects of students who come from the internal factors of the students themselves as individuals who will learn. After paying attention to these things, the teacher must be able to carefully determine the appropriate learning strategy to be applied in the learning process. They are considering this need to be researched to describe junior high school mathematics learning activities and describe the suitability of the Brain Based Learning (BBL) learning strategy by paying attention to intrapersonal intelligence in mathematics learning in junior high school.

\section{Literature Review}

The concept of learning strategies can be interpreted as various types of plans used by the teacher to achieve goals (Silver et al., 2012). In simple terms, this view states that learning strategies are ways to do something in achieving goals. Another opinion says that learning strategies that involve students actively in the learning process through scientific research will further enhance conceptual understanding rather than strategies with passive techniques (Joyce, Weil, \& Calhoun, 2009). This view emphasizes activities that accommodate improvisation, involvement, and students' response. Another opinion uses different designations state as an instructional strategy which is a combination of the sequence of activities, ways of organizing subject and student materials, equipment and materials, and the time used in the instructional process to achieve predetermined learning goals (Suparman, 2010). Instructional strategies in this opinion are referred to as a systematic way of communicating lesson content to students to achieve learning objectives.

Branch (2009) argues that learning strategies are organizations and sequences of learning activities (Branch, 2009). In line with this opinion, learning strategies are said to refer to learning activities that are planned and implemented in the process of developing learning (Jonassen, 2013). The two opinions above reveal that learning strategies are structured activities that are deliberately intended to take place during the learning process. While Dick, Carey, and Carey (2009) say that 
learning strategies are used in general, and include various aspects in choosing multiple delivery systems, order and grouping content, explaining the components in learning, determining the structure of the lesson and selecting learning media (Dick, Carey, \& Carey, 2009). This view expressed explains the scope of the learning strategy for all things that must be considered in the learning process.

Brain-Based Learning (BBL), as a learning strategy, is a concept to create learning that is oriented towards efforts to empower students' brain potential. BBL emphasizes students so they can develop their brains to solve a problem or build information that they obtain. The principle in BBL is that the brain is a parallel processor which means it can do several activities at once, learning involves all physiology, searching for meaning, emotions are essential for the whole process of the process and parts of the brain simultaneously. Another principle of BBL is that learning involves both concentration and peripheral perceptions, learning requires both conscious and unconscious processes, memorization, the brain understands the best facts when embedded in spatial memory, learning is enhanced and inhibited by challenges and threats, and each brain is unique (Jensen, 2008).

The application of the BBL learning strategy creates a learning environment that challenges students' thinking skills, fun, active and meaningful learning situations for students. It takes a little time to learn how the brain works in understanding a problem, requires adequate facilities to support learning practices, and requires costs in creating a learning environment that is good for the brain. In applying the BBL, it should be harmonized with all stages in learning so that teachers can optimize the potential of students' brains. The brain works have a significant impact on the effectiveness of learning activities. The teacher needs to help students have appropriate experience and utilize the experience. Knowing how the brain works best allows the teacher to create a learning environment that gives students the opportunity for higher success in learning. Through the application of BBL, it will familiarize teachers in planning careful learning, knowledge of brain research findings, and a little creativity; teachers can offer engaging and brain-based activities that encourage exploration and learning and support learning standards. Teachers and students can build an active learning environment that sees learning as an opportunity to be a successful problem solver while anticipating each new challenge as an exciting learning experience (Ramakrishnan \& Annakodi, 2013).

One of the internal factors of students that teachers need to consider in learning activities is the level of intelligence of students. One type of intelligence that is also important is intrapersonal intelligence (Gardner, 2003). The concept of intrapersonal intelligence is also said as self-knowledge which is intelligence that involves self-awareness or self-sensitivity, the process of thinking, awareness of changes that occur in oneself, requires the skills of cooperating and communicating both verbally and nonverbally (Alder, 2001). Intrapersonal intelligence lies in a person who is characterized by the ability to understand themselves and act on that understanding. The intended ability is the ability to recognize strengths in themselves, their shortcomings, self-limitations, intelligence on emotions or moods, desires, motivations, intentions, and goals, and to respect themselves and control themselves.

Based on the definition, three components of intrapersonal intelligence can be identified, namely the ability to experience different feelings deeply with passion, enthusiasm, and spontaneity, the ability to be assertive and recognition of self-esteem (Amstrong, 2002). This ability also includes the ability to analyze oneself, know well about himself, what he wants, what to do, what is best for him, and how to respond to specific situations, and react to them well, and self-reflection. This self-understanding is very good to help someone develop their potential and help them to express themselves better, and be able to work optimally. Intrapersonal intelligence has the benefit of building self-image and self-esteem, controlling emotions, being able to be accountable to oneself.

Learning strategies and internal factors of students are two things that must be considered by the teacher in planning and designing learning activities, in this case, including mathematics learning. Learning is more directed at construction than instruction, which has implications for the role of teachers and students (Reigeluth \& Carr-Chellman, 2009). This concept reveals that in learning activities students construct their knowledge. Construction refers to students who are more active in completing things in the learning process so that there is a relatively permanent process of influence on students in the form of knowledge, attitudes, and skills acquired through experiences designed by teachers (Santrock, 2010). Concerning learning in the meaning of this construction, Joyce, Weil, and Calhoun (2009) state that teachers must facilitate students in obtaining information, ideas, skills, values, ways of thinking and goals of expressing themselves (Joyce et al., 2009). Implicitly these views explain the role of the teacher in learning which involves students in tasks that are loaded with challenges and creativity so that it makes it easier for students to absorb and master information while the role of students can describe information and ideas through the use of various existing learning resources.

The various learning concepts described above provide an understanding of the learning activities that should occur. The knowledge is that learning activities must be deliberately planned and designed by the teacher to create a learning process that can actively involve students. Students must actively interact with various learning resources that exist in developing their potential to improve the expected competencies. This kind of learning activity must be applied to all subjects taught at school. 
One of the subjects taught at school is mathematics. Kline (1962) states that mathematics breaks down numbers, constructs geometric space, and expands ideas about numbers and constructs of geometric space (Kline, 1962). Another view says that mathematics is a science of logic concerning the form, arrangement of magnitudes, and related concepts which are divided into three fields, namely algebra, analysis and geometry (James \& James, 1976). Mathematics is also called a thinking pattern, a pattern of organizing and logical proof that is carefully defined, clear, accurate and represented by symbols (Johnson \& Rising, 1972). Meanwhile, Kneebone (2001) briefly states that mathematics is only the study of general structures or regular patterns of connectedness (Kneebone, 2001). Referring to the above views, mathematics is a science of logic that is built and described with symbols or language symbols, and systematically defined and interrelated between existing concepts. The logic is developed, explained and the proof through deductive reasoning.

The concept of mathematical learning is closely related to learning theory, the formulation of learning and the definition of mathematics itself. Watchel (2007) states that mathematics learning is learning about composing numbers, geometry and mathematical concepts (Wachtel, 2007). Another similar opinion states that mathematics learning as a learning process that involves students actively in constructing mathematical knowledge (Cobb, 2013). The two formulas emphasize the activities of students building mathematics subject matter, thinking logically, collapsing and creative. Mathematics learning is seen as a process of developing students' creativity to improve their ability to believe in constructing knowledge to have a good mastery of mathematics subject matter.

Learning mathematics, according to Bruner (2009), is learning about the concepts and structure of mathematics and looking for relationships between the two on the material being studied (Bruner, 2009). This view focuses on solving problems, forming mindsets, understanding, and reasoning for a relationship in mathematical material. Meanwhile, Dienes (2008) revealed that mathematics learning is a learning activity that involves a hierarchical structure of high-level concepts that are built based on existing initial concept formation (Dienes, 2008). Similar thoughts state that in learning activities, learning materials must be adapted to the abilities and cognitive structures of students. Learning material must be related to the concepts that are already owned so that new ideas can be fully absorbed by students (Ausubel, 2012). Both of these thoughts emphasize that in mathematics learning activities that occur must be gradual and sequential and always based on past learning experiences.

\section{Methodology/Materials}

The research approach used in this study is qualitative with descriptive methods and literature studies. This research was conducted at SMP Assahil Lampung Timur in the 2018/2019 academic year. Respondents in this study were students and mathematics teachers. Data collection techniques in this study used documentation studies, observations, and interviews. Data analysis uses quantitative and qualitative descriptive analysis. The quantitative descriptive analysis describes the data collected and presented in the form of tables and graphs related to mathematics learning outcomes over the past three years. Qualitative descriptive analysis reveals events or facts, circumstances, and phenomena that occur by interpreting and interpreting the collected data related to the learning process of mathematics that has been going on.

\section{Results and Findings}

In general there are six characteristics of mathematics, namely having abstract study objects, referring to the agreement, deductive thinking, consistent in the system, having symbols that are empty of meaning, and paying attention to the universe of conversation (Soedjadi, 2000). The object of study which is abstracts of mathematics in school includes facts, concepts, operations, and principles whose discussion refers to the agreement. Statements of mathematics are obtained through a deductive mindset. The meaning and truth value of statements in the system of mathematics applies the law of consistency. Namely, there is no contradiction in it. An empty mathematical symbol or model of meaning so it must always be associated with the universe of conversation in every problem-solving.

At the junior high school level, the characteristics of mathematics subject matter are determined through Minister of Education and Culture Regulation number 37 of 2018 which regulates Core Competencies (KI) and Basic Competencies (KD) lessons in the 2013 curriculum in primary and secondary education. The appendix 15 of the regulation contains KI and KD of SMP/MTs mathematics in which it explains the material characteristics for each grade level. For 7 th grade, the attributes of the subject matter include factual, conceptual and procedural of numbers, sets, algebraic forms, social arithmetic, relationships between angles, various types of quadrants and the relationship between data by way of presentation. In 8th grade, the characteristics are factual, conceptual and procedural including the pattern on the line, the field of cartesian coordinates, relations, functions, Pythagoras, angles, tangents, building space, data distribution, and opportunities. Whereas 9th-grade characteristics are factual, conceptual and procedural from the form of roots, quadratic equations, geometric transformations, flat and built spaces.

The characteristics of junior high school students according to their age ranging from 12 to 15 years are early adolescents. These characteristics include physical, 
emotional, social, personality, intellectual and moral development (Santrock, 2017). Physically, adolescents experience significant structural changes, but emotional development has not reached maturity, especially in terms of controlling feelings. The social construction of adolescents is at the stage of seeking identity and self role while for personality development five things become factors namely openness, prudence, sociability, friendliness, and emotional stability. Junior high school students as early adolescents enter intellectual development which is at the formal operational stage (Piaget \& Inhelder, 2010). In moral development, junior high school students enter the conventional level stage which is related to the consequences of social actions and rules.

SMP Assahil students have characteristics like teenagers in general. Most of the students of SMP Assahil are indeed santri at the Assahil Islamic Boarding School so that the characteristics of the santri are also attached to these students. The characteristics of santri, in general, include obedience, independence, simplicity, togetherness, and kinship (Purwoko, Jahi, Asngari, Gani, \& Hisyam, 2017). Compliance of santri towards kyai and the ustadz especially in religious matters so that they have independence in managing and fulfilling all their own needs. The limitations of what in a boarding school makes the santri have simplicity, togetherness, and kinship in carrying out all their daily activities (Purwoko et al., 2017). The characteristics of the santri are suited with aspects that become a benchmark for one's intrapersonal intelligence.

Understanding of the characteristics of mathematics subject matter and the characteristics of students in junior high school becomes a reference for teachers in choosing the learning strategies that will be applied. Many learning strategies can be selected by the teacher to be involved in the process of learning mathematics. Some learning strategies that can be chosen include expository, inquiry, problem-based learning, increased thinking ability, cooperative, contextual, project-based learning, and brain-based learning. Each learning strategy has its characteristics. Learning strategies implementd by teachers must also pay attention to students' internal factors; one of them is the level of intelligence (Sumantri, 2015).

During this time the learning strategies applied by the mathematics teacher at SMP Assahil based on information and observations showed characteristics that suited expository learning strategies. There are at least three characteristics of expository learning strategies, namely verbal material delivery, the material delivered and mastery of subject matter (Sanjaya, 2013). The teacher plays a very dominant role in the learning process using this strategy. An expository learning strategy is a form of teacher-centered learning approach. Instead, it is necessary for teachers to implement student-oriented learning strategies that are believed to be able to improve students' learning outcomes further.
Many alternatives can be used by the teachers to improve the quality of the learning process carried out. The option is among others through the selection of the right learning strategies to be applied, like student-oriented learning strategies. It is learning strategies that suit the characteristics of the subject matter and student characteristics. The application of appropriate learning strategies will facilitate the achievement of defined learning goals and can improve students' learning outcomes (Syakdiyah, Wibawa, \& Muchtar, 2018). Many strategies can be chosen by the teacher to be applied in learning activities. Important things that are taken into consideration in the selection of learning strategies are related to the support of psychological theory and theories about learning as well as those associated with the effectiveness of achieving learning objectives. Both of these are also associated with the learning design process which must both consider learning objectives, students' characteristics, technical implementation of learning and assessment needs. All of these are taken into consideration when deciding which learning strategies are suitable for the application.

In addition to learning strategies, other things that need to be considered by the teacher in the learning process are students' internal factors. The internal factors of students include physiological and psychological factors. Physiological or physical factors, namely something are innate or hereditary as well as those obtained, such as vision, hearing, body structure and so on. Psychological factors are also congenital or acquired, which consist of intellectual factors or potential factors such as intelligence and talent and real factors or real skills, such as achievement. Non-intellectual psychological factors are components of individual personalities such as attitudes, interests, habits, needs, motivation, self-concept, self-adjustment, emotional and so on. To improve students' learning outcomes, teachers need to pay attention to these internal factors which are characteristics of students (Salam, Ibrahim, \& Sukardjo, 2018).

The linkages between learning strategies and students' internal factors towards learning outcomes have been strengthened by several research results including the findings conveyed by Sumantri and Supendi (2010) that the learning strategies applied by the material characteristics taught can improve student's learning outcomes (Sumantri \& Supendi, 2015). Another finding suggests that the application of the Brain Based Learning (BBL) learning strategy of teachers can improve students' conceptual understanding of mathematics learning which has a positive effect on learning outcomes (Suarsana, Widiasih, \& Suparta, 2018). Related to the correlation of students' internal factors to the learning outcomes of mathematics there have been many research findings produced; one of them was conducted by Ibrahim (2012) which revealed that internal factors in the form of achievement motivation students have a positive relationship with learning 
outcomes (Ibrahim, 2012). Referring to these findings, it can be said that high student achievement motivation can improve mathematics learning outcomes. Based on the description of the conditions above, the mathematics learning outcomes of junior high school students are highly dependent on the learning strategies applied by the teacher by considering the internal factors of the students.

In mathematics learning, the applied learning strategy must be able to involve students actively in using their thinking potential in solving math problems. These characteristics suit the Brain Based Learning (BBL) learning strategy which emphasizes that students play an active role in constructing the concepts learned (Ulger, 2018). There are three steps in the BBL learning strategy, namely:

\section{1) Creating a learning environment that challenges} students' thinking skills (orchestrated immersion)

The phase is orchestrated immersion focused on making the subject matter in learning more meaningful and enduring in the students' memories. This phase helps students make patterns and associate with their brains when they are given problems that are rich in learning experiences so that the learning gained will last longer in the memory of students. In each learning activity, it is necessary to provide subject matter questions that facilitate students' thinking skills. The lesson questions are as functional and interesting as possible, for example through puzzles, simulation games, etc, so that students can get used to developing their thinking skills in the context of empowering students' brain potential.

\section{2) Creating a learning environment relaxed}

For the phase relaxed alertness, students are challenged to solve a problem well but minimize the threats that can be obtained if they cannot do their best, because learning outcomes become higher when someone is comfortable without risks. Learning can be varied by bringing students to study outside the classroom at certain times, accompanying learning activities with music that is appropriately designed according to the needs in the classroom, learning activities with group discussions interspersed with exciting games, and other efforts that eliminate discomfort in students.

3) We are creating actual and meaningful learning situations for students (active processing).

The phase is active processing done by forming study groups that facilitate students so that students can absorb information well, but students must still be given awards even though the results of their performance are not optimal. Students are stimulated through learning activities to be able to build their knowledge through the active learning process that they do themselves. Make a learning situations that allow all members of the student body to move optimally, for example, the eyes of students are used to read and observe, students' hands move to write, students' legs move to play in learning, mouths of students actively ask and discuss, and productive activities of other limbs.

The internal factors of students are expected to support the creation of learning conditions that apply the BBL learning strategy namely intrapersonal intelligence of students. Three main aspects can be used as benchmarks, namely:

1) Identifying yourself

The aspect of recognizing yourself is an accurate and realistic ability regarding the strengths and weaknesses of one's potential which includes emotional awareness, assertiveness, self-esteem, independence, thought processes, self-discipline, and self-actualization.

\section{2) Knowing your own desires}

Aspects of knowing your desires are the ability to identify your own needs to encourage you to fulfill them which include self-motivation, skills in set finding goals and clear and precise steps.

\section{3) Knowing what is necessary to oneself}

The aspect of knowing which is needed for oneself is the ability to qualify the sequence of needs or self-interests which include, among others, the attitude of making the right decisions based on the values of self-consideration.

The implementation of mathematics learning in schools requires stages of learning by students' mental and cognitive development. This condition includes the presentation, mindset, limitations of the universe, and the level of abstractness that must be adapted to the intellectual development of students. Mathematics subject matter must be delivered in stages from real concepts to more abstract concepts using symbols. The purpose of mathematics is taught in school so that students can understand mathematical concepts, use reasoning, problem-solving, communicate ideas and have an attitude towards appreciating the usefulness of mathematics in life.

Referring to the ideas about mathematics learning that have been stated previously, mathematics learning is a process that is deliberately designed to create a learning atmosphere that allows students to learn mathematics actively. There is a process of interaction between teachers, students and learning environments that are deliberately created by teachers with various strategies. Interactions that allow students to experience meaningful learning. Students can associate new knowledge with structures that have been previously owned. Mathematical learning that is capable of constructing knowledge involves transforming information, discovering new concepts and experiences in learning mathematics. Pay attention to that, it can be stated that conceptually there is a match between the characteristics of junior high school mathematics material, the features of BBL learning strategies and the characteristics of intrapersonal intelligence that have a potentially positive impact on the learning process of mathematics and can improve students' learning outcomes. 


\section{Conclusions}

In mathematics learning at SMP Assahil LampungTimur, students only receive knowledge passively. Students have not been able to construct their knowledge, so learning becomes less meaningful. The condition is evidenced in the mathematics learning outcomes that are less satisfactory and relatively low for the past three years. Based on the results of the study of documentation, observation, and interviews conducted, it was found that the learning activities that had taken place so far only used expository learning strategies. The teacher has never made a selection of learning strategies by paying attention to students' internal factors to be applied in learning. In concept, there is a match among the characteristics of junior high school mathematics material, the characteristics of BBL learning strategies and the characteristics of intrapersonal intelligence. Based on this, it is very potential for junior high school mathematics learning to apply BBL learning strategies by considering intrapersonal intelligence, to improve students’ learning outcomes.

\section{Acknowledgement}

This research was supported by Universitas Negeri Jakarta and SMP Assahil Lampung Timur, for which thanks to 1) Doctoral Program in Educational Technology, Postgraduate Program at Universitas Negeri Jakarta; 2) SMP Assahil Lampung Timur; 3) Prof. Dr. M. Syarif Sumantri, M.Pd. as the promoter and Prof. Dr. Nurdin Ibrahim, M.Pd. as the co. promoter who always provides input and guidance for the author.

\section{REFERENCES}

[1] Alder, H. (2001). Boost Your Intelligence: Pacu EQ dan IQ Anda. Jakarta: Erlangga.

[2] Amstrong, T. (2002). ldentifying and Developing Your Multiple Intelligences. Jakarta: Gramedia Pustaka Utama.

[3] Ausubel, D. P. (2012). The Acquisition and Retention of Knowledge: A Cognitive View. New York: Springer Science \& Business Media.

[4] Branch, R. M. (2009). Instructional Design: The ADDIE Approach. New York: Springer Science \& Business Media.

[5] Bruner, J. S. (2009). The Process of Education: A Landmark in Educational Theory (Revised Ed). Cambridge: Harvard University Press.

[6] Cobb, P. (2013). Learning Mathematics: Constructivist and Interactionist Theories of Mathematical Development. New York: Springer Science \& Business Media.

[7] Dick, W., Carey, L., \& Carey, J. O. (2009). The Systematic Design of Instruction. New Jersey: Pearson.
[8] Dienes, Z. P. (2008). Mathematics Education and the Legacy of Zoltan Paul Dienes. (B. Sriraman, Ed.). Charlotte: Information Age Pub.

[9] Eggen, P., \& Kauchak, D. (2012). Strategi dan Model Pembelajaran, Mengajarkan Konten dan Keterampilan Berpikir. Jakarta: PT. Indeks.

[10] Gardner, H. (2003). Multiple Intelligences: Kecerdasan Majemuk Teori dalam Praktek. Batam: Interaksara.

[11] Ibrahim, N. (2012). Meningkatkan Hasil Belajar Matematika dengan Blended Learning dan Motivasi Berprestasi Siswa. Perspektif Ilmu Pendidikan, 26(XVII).

[12] James, G., \& James, R. C. (1976). Mathematics Dictionary. New Jersey: John Wiley \& Sons.

[13] Jensen, E. (2008). Brain-Based Learning: The New Paradigm of Teaching. Thousand Oaks: Corwin Press.

[14] Johnson, D. A., \& Rising, Gerald R. (1972). Guidelines for Teaching Mathematics. California: Wadsworth Publishing Company Inc.

[15] Jonassen, D. H. (2013). Learning, Problem Solving, and Mindtools. New York: Routledge.

[16] Joyce, B., Weil, M., \& Calhoun, E. (2009). Model-model Pembelajaran (8th ed.). Yogyakarta: Pustaka Pelajar.

[17] Kline, M. (1962). Mathematics: A Cultural Approach. New York: Addison-Wesley.

[18] Kneebone, G. T. (2001). Mathematical Logic and The Foundations of Mathematics: An Introductory Survey. New York: Dover Publications.

[19] Piaget, J., \& Inhelder, B. (2010). Psikologi Anak (The Psychology of The Child). Yogyakarta: Pustaka Pelajar.

[20] Purwoko, D., Jahi, A., Asngari, P. S., Gani, D. S., \& Hisyam, M. (2017). Hubungan Karakteristik Santri dengan Persepsi Mereka Tentang kemandirian di Pondok Pesantren. Jurnal Penyuluhan Institut Pertanian Bogor, 3(2), 72.

[21] Ramakrishnan, J., \& Annakodi, R. (2013). Brain Based Learning Strategies. International Journal of Innovative Research \& Studies, 2(5).

[22] Reigeluth, C. M., \& Carr-Chellman, A. A. (2009). Instructional-Design Theories and Models: Building a Common Knowledge Base (3rd ed.). New York: Routledge.

[23] Salam, M., Ibrahim, N., \& Sukardjo, M. (2018). The Effect of Learning Model and Spatial Intelligence on Learning Outcome. In The Third International Conference on Mathematics, Science, Technology, Education and Their Applications (3rd ICMSTEA) 2018. Makassar.

[24] Sanjaya, W. (2013). Strategi Pembelajaran Berorientasi Standar Proses Pendidikan. Jakarta: Kencana.

[25] Santrock, J. W. (2010). Psikologi Pendidikan. Jakarta: Kencana.

[26] Santrock, J. W. (2017). Life Span Development (Perkembangan Masa Hidup) (13th ed.). Jakarta: Erlangga.

[27] Silver, H. F., Strong, R. W., \& Perini, M. J. (2012). Strategi-Strategi Pengajaran: Memilih Strategi Berbasis Penelitian yang Tepat untuk Setiap Pelajaran. Jakarta: PT. 
Indeks.

[28] Soedjadi, R. (2000). Kiat Pendidikan Matematika di Indonesia: Konstatasi Keadaan Masa Kini Menuju Harapan Masa Depan. Jakarta: Direktorat Jenderal Pendidikan Tinggi.

[29] Suarsana, I. M., Widiasih, N. P. S., \& Suparta, I. N. (2018). The Effect of Brain Based Learning on Second Grade Junior Students' Mathematics Conceptual Understanding on Polyhedron. Journal on Mathematics Education, 9(1).

[30] Sumantri, M. S. (2015). Strategi Pembelajaran Teori dan Praktik di Tingkat Pendidikan Dasar. Jakarta: PT. Rajagrafindo Persada.

[31] Sumantri, M. S., \& Supendi. (2015). The influence of learning strategy resolution based toward environmental health learning result observed by students' concept. International Journal of Research Studies in Education, 4(1), 31-41.

[32] Suparman, A. (2010). Desain Instruksional. Jakarta: Universitas Terbuka.

[33] Syakdiyah, H., Wibawa, B., \& Muchtar, H. (2018). The Effect of Flipped Classroom and Problem Based Learning Strategies in High School Chemistry Education. The Journal of Social Sciences Research, 2, 505-511.

[34] Ulger, K. (2018). The Effect of Problem Based Learning The Creative Thinking and Critical Thinking Disposition of Student in Visual Arts Education. Interdisciplinary Journal of Problem Based Learning, 12.

[35] Wachtel, L. (2007). Learning Mathematics in The Intermediate Grades. Dayton: The Madison Metropolitan School District. 